\title{
Effects of metabolic syndrome on aortic pulse wave velocity
}

\author{
Dong-Hyeon Lee, Ho-Joong Youn", Woo-Baek Chung, Yun-Seok Choi, Jong-Min Lee, Chul-Soo Park, Hae-Ok Jung, \\ Hui-Kyung Jeon and Man-Young Lee
}

\begin{abstract}
Background: The purpose of this study was to compare the value and evaluate the validity of non-invasive methods for the detection of vascular stiffness in never-treated individuals with metabolic syndrome (MetS).

Methods: A total of 59 subjects (mean age, $60 \pm 12$ years; male:female $=35: 24$ ) were enrolled in the study and were categorized into the positive MetS (MetS[+]: $N=32$ ) and negative group (MetS[-]: $N=27$ ), according to the parameters set by the National Cholesterol Education Program's Adult Treatment Panel III. Pulse wave velocity (PWV) of the aorta, arm, and leg, Framingham risk score (FRS), ankle-brachial index (ABI), and carotid intima-media thickness (IMT) for vascular aging were measured for the two groups.

Results: Aortic PWW (PWaor) was significantly higher in MetS(+) than MetS(-) group $(7.0 \pm 1.4 \mathrm{~m} / \mathrm{s}$ vs. $8.4 \pm 1.6 \mathrm{~m} / \mathrm{s}, p$ $<0.01$ ), while $\mathrm{ABI}$ was significantly lower in MetS(+) than MetS(-) group (1.2 $\pm 0.1 \mathrm{vs.} 1.1 \pm 0.2, p=0.03)$, respectively. FRS was significantly higher in MetS(+) than MetS(-) group (11 \pm 5 vs. $14 \pm 4, p=0.05)$. The both mean IMT was higher in MetS(+) than MetS(-) group (right: $0.94 \pm 0.20 \mathrm{~mm}$ vs. $0.81 \pm 0.20 \mathrm{~mm}, p=0.03$; left: $0.93 \pm 0.20 \mathrm{~mm}$ vs. $0.79 \pm 0$. $20 \mathrm{~mm}, p=0.03$, respectively). For predicting the probability of the presence of MetS, PWaor was an independent tool ( $p=0.04$; odds ratio, 1.88; 95\% confidence interval, 1.03 to 3.42) and a cut-off value of PWaor of $7.4 \mathrm{~m} / \mathrm{s}$ showed a sensitivity of $66.7 \%$ and a specificity of $47.6 \%$.
\end{abstract}

Conclusions: We suggest that PWaor, combined with traditional tools, can play an important role as a complementary or alternative tool for the detection of vascular stiffness in never-treated individuals with MetS.

Keywords: Aorta, Pulse wave velocity, Metabolic syndrome

\section{Background}

Metabolic syndrome (MetS), characterized by a combination of several cardiovascular and metabolic risk factors including central obesity, dyslipidemia, elevated blood pressure, and impaired glucose tolerance [1,2], is a worldwide health problem associated with both subclinical atherosclerosis and an increased risk of cardiovascular events [3]. It is well established that MetS not only is an accelerator of central arterial aging but also an independent predictor of cardiovascular events in older subjects $[4,5]$.

There are several tools for the measurement of the relationship between cardiovascular risk factors and

\footnotetext{
*Correspondence: younhj@catholic.ac.kr

Division of Cardiology, Department of Internal Medicine, Seoul St. Mary's

Hospital, The Catholic University of Korea College of Medicine, \#505

Banpo-dong, Seocho-gu, Seoul 137-701, South Korea
}

vascular aging, including Framingham risk score (FRS) [5], which estimates 10-year risk of coronary heart disease (CHD); ankle-brachial index (ABI) [6, 7], which is used to assess and evaluate the presence of peripheral arterial disease (PAD) of the lower extremities; pulse wave velocity (PWV), pulse pressure (PP), and augmentation index (AIx), which reflect systemic arterial stiffness are significantly and independently associated with both target organ damage and increased risk for cardiovascular morbidity and mortality; subendocardial viability ratio (SEVR), which estimates myocardial perfusion relative to cardiac workload; ejection duration (ED), which reflects cardiac function by assessing the duration of left ventricular systolic ejection (systolic time interval in milliseconds) [7-9]; and intima-media thickness (IMT) of carotid artery [10-12]. 
The purpose of this study was to compare the value and evaluate the validity of non-invasive methods, including FRS, ABI, PWV, AIx, SEVR, ED, and carotid IMT for the detection of vascular stiffness in nevertreated individuals with MetS.

\section{Methods}

\section{Participants}

From a total of 71 subjects, 12 subjects on antihypertensive drugs, oral hypoglycemic agents or insulin, lipid-lowering medication, or non-steroidal anti-inflammatory drugs (aspirin) were excluded.

Fifty-nine individuals (male $[\mathrm{M}]$ :female $[\mathrm{F}]$ ratio $=35: 24$; mean age, $60 \pm 12$ years) who visited the outpatient clinics of the St. Mary's Hospital between March 2012 and August 2012 were enrolled in this study and they were divided into the positive MetS (Mets[+]: $N=32$; M:F ratio $=19: 13$; mean age, $62 \pm 12$ years) and negative group (Mets[-]: $N=27$; M:F ratio $=16: 11$; mean age, $59 \pm 11$ years), in accordance with the 2005 Adult Treatment Panel III criteria [2]. MetS(+) was defined as the presence of at least three of the following five components: (1) abdominal obesity (waist circumference $>90 \mathrm{~cm}$ in men and $>80 \mathrm{~cm}$ in women); (2) triglycerides $\geq 150 \mathrm{mg} / \mathrm{dL}$; (3) high density lipoprotein (HDL) cholesterol $<40 \mathrm{mg} / \mathrm{dL}$ in men or $<50 \mathrm{mg} / \mathrm{dL}$ in women; (4) blood pressure $\geq 130 / 85 \mathrm{mmHg}$; and (5) fasting plasma glucose $100 \mathrm{mg} / \mathrm{dL}$ [2].

This study was approved by the institutional review committee of St. Mary's Hospital. Patients were informed of the investigative nature of the study and written informed consent was obtained before enrollment (SC 14RISI0006).

\section{Anthropometric parameter measurement}

Waist circumferences were measured using a standardized tape by the same well-trained staff. The tape was calibrated before use. The waist circumference was measured 1 inch above the umbilicus in the standing position. Systolic blood pressure (SBP), diastolic blood pressure (DBP), mean arterial pressure (MAP), and PP in both brachial artery and ankles were simultaneously measured using automated oscillometric devices (Omron HEM712C; Omron, Tokyo, Japan) with subjects in a seated position after resting quietly for $10 \mathrm{~min}$. ABI was defined as the ratio between the systolic pressure measured in the ankle and that measured in the brachial artery.

\section{Biochemical assays}

Blood samples were drawn for the analysis of levels of fasting plasma glucose, total cholesterol, triglyceride, HDL cholesterol, low density lipoprotein cholesterol and high-sensitivity $\mathrm{C}$-reactive protein.

\section{Framingham risk score}

FRS was calculated on the basis of a number of categorical variables, including age, total cholesterol level, HDL cholesterol level, SBP, treatment for hypertension, and cigarette smoking [1]. The 10-year risk for myocardial infarction and CHD is estimated from total points, and the person is categorized according to absolute 10-year risk as indicated above [1].

\section{Pulse wave velocity of the aorta, the arm, and the leg, augmentation index, subendocardial viability ratio, and ejection duration}

PWV of the aorta, the arm and the leg (PWVaor, PWVarm and PWVleg), were measured using an automatic waveform analyzer (PP-1000; Hanbyul Meditech Co., Jeonju, Korea), which provides regional PWV values based on the results of electrocardiography, phonocardiography, and then automatically recorded pulse waves from four different arteries (carotid, femoral, radial, and dorsalis pedis) on the left side of the body for $10 \mathrm{~s}$. PWVaor was determined as the velocity between the carotid and femoral arteries. PWVarm and PWVleg were calculated based on the carotid-radial and the femoraldorsalis pedis pulse transit times, respectively.

The three main indices of cardiovascular function, namely AIx, SEVR, and ED, were measured using (GAON; Hanbyul Meditech Co., Jeonju, Korea), and were defined as follows: AIx, as the ratio of the augmentation pressure to PP; SEVR, as the ratio of the diastolic pressure time integral to the systolic pressure time integral; and ED, as the duration of systolic ejection to the total duration of a cardiac cycle. The pressures (i.e., SBP, DBP, MAP, and PP) obtained from aortic pulse wave referred to as central blood pressure.

\section{Carotid Intima-media thickness}

Carotid IMT was measured at the common carotid and internal carotid arteries by B-mode ultrasound using a $15 \mathrm{MHz}$ linear transducer $(15 \mathrm{MHz}$ transducer with Sonos 5500; Philips, Andover, MA, USA) following a standardized protocol. A minimum of seven measurements of common carotid far (posterior) wall were taken $20 \mathrm{~mm}$ proximal to the bifurcation to derive mean carotid IMT values. For statistical analysis, mean carotid IMT was calculated by averaging the thickness at four sites at the far walls of both the right and left distal common carotid arteries, two each from the right and left arteries. The physicians who performed the evaluation were blind to the health status and clinical characteristics of the study participants. A single welltrained sonographer who was blinded to clinical information made all the measurements. 


\section{Statistical analysis}

Continuous variables are expressed as mean \pm standard deviation. Among five groups classified by the number of MetS components, comparisons of FRS were performed using the analysis of variance test. For comparisons between MetS(+) and MetS(-) groups, analysis for categorical data was performed using chi-square test and comparison for variable parameters was analyzed using independent $t$-test; all analyses were conducted using SAS statistical software ver. 9.1 (SAS Institute Inc., Cary, NC, USA). Multivariate logistic regression analysis was used to determine an independent tool for predicting the probability of the presence of MetS. Statistical significance was set at $p<0.05$.

\section{Results}

Fifty-nine individuals (M:F ratio $=35: 24$; mean age, $60 \pm$ 12 years $)$ were divided into the $\operatorname{MetS}(+)(N=32$; M:F ratio $=19: 13$; mean age, $62 \pm 12$ years) and $\operatorname{MetS}(-)$ group $(N=27 ; \mathrm{M}: \mathrm{F}$ ratio $=16: 11$; mean age, $59 \pm 11$ years $)$. The baseline clinical and laboratory findings of the two groups are summarized in Table 1.

FRS was significantly higher in the $\operatorname{MetS}(+)$ than MetS(-) group (11 \pm 5 vs. $14 \pm 4, p<0.01)$ (Fig. 1a). There

Table 1 Baseline characteristics

\begin{tabular}{|c|c|c|c|}
\hline Variable & MetS(-) group $(N=27)$ & $\operatorname{Met} S(+)$ group $(N=32)$ & $p$-value \\
\hline Age (yr) & $59 \pm 11$ & $62 \pm 12$ & 0.20 \\
\hline Gender (male) & $16(59.3)$ & $19(59.4)$ & 0.99 \\
\hline \multicolumn{4}{|l|}{ Waist circumference (cm) } \\
\hline Male & $88 \pm 7$ & $93 \pm 7$ & 0.07 \\
\hline Female & $88 \pm 14$ & $88 \pm 7$ & 0.96 \\
\hline $\mathrm{SBP}(\mathrm{mmHg})$ & $124 \pm 20$ & $128 \pm 14$ & 0.42 \\
\hline $\mathrm{DBP}(\mathrm{mmHg})$ & $75 \pm 7$ & $74 \pm 12$ & 0.65 \\
\hline MAP (mmHg) & $91 \pm 12$ & $93 \pm 8$ & 0.37 \\
\hline PP (mmHg) & $52 \pm 21$ & $53 \pm 11$ & 0.85 \\
\hline Central SBP (mmHg) & $114 \pm 12$ & $117 \pm 11$ & 0.47 \\
\hline Central DBP (mmHg) & $78 \pm 11$ & $77 \pm 7$ & 0.73 \\
\hline Central MAP (mmHg) & $93 \pm 10$ & $94 \pm 8$ & 0.77 \\
\hline Central PP (mmHg) & $37 \pm 14$ & $40 \pm 9$ & 0.34 \\
\hline Ankle-brachial index & $1.2 \pm 0.1$ & $1.1 \pm 0.2$ & 0.03 \\
\hline Fasting plasma glucose (mg/dL) & $100 \pm 8$ & $120 \pm 23$ & $<0.01$ \\
\hline Hemoglobin A1c (\%) & $5.8 \pm 0.5$ & $6.4 \pm 1.3$ & 0.45 \\
\hline Total cholesterol (mg/dL) & $179 \pm 38$ & $182 \pm 44$ & 0.76 \\
\hline Triglyceride (mg/dL) & $103 \pm 37$ & $184 \pm 113$ & $<0.01$ \\
\hline High density lipoprotein cholesterol (mg/dL) & $49 \pm 13$ & $42 \pm 11$ & 0.02 \\
\hline Low density lipoprotein cholesterol (mg/dL) & $111 \pm 34$ & $108 \pm 31$ & 0.78 \\
\hline C-reactive protein (mg/L) & $1.25 \pm 2.09$ & $2.15 \pm 2.07$ & 0.06 \\
\hline Framingham risk score & $11 \pm 5$ & $14 \pm 4$ & $<0.01$ \\
\hline \multicolumn{4}{|l|}{ Pulse wave velocity } \\
\hline Aorta $(\mathrm{m} / \mathrm{sec})$ & $7.0 \pm 1.4$ & $8.4 \pm 1.6$ & $<0.01$ \\
\hline $\operatorname{Arm}(\mathrm{m} / \mathrm{sec})$ & $8.0 \pm 1.5$ & $8.8 \pm 1.2$ & 0.07 \\
\hline $\operatorname{Leg}(\mathrm{m} / \mathrm{sec})$ & $9.4 \pm 1.4$ & $9.6 \pm 1.6$ & 0.68 \\
\hline Augmentation index (\%) & $78 \pm 20$ & $89 \pm 25$ & 0.12 \\
\hline Subendocardial viability ratio (\%) & $122 \pm 21$ & $126 \pm 30$ & 0.64 \\
\hline Ejection duration (ms) & $352 \pm 43$ & $337 \pm 43$ & 0.30 \\
\hline Right mean IMT (mm) & $0.81 \pm 0.20$ & $0.94 \pm 0.20$ & 0.03 \\
\hline Left mean IMT (mm) & $0.79 \pm 0.20$ & $0.93 \pm 0.20$ & 0.03 \\
\hline
\end{tabular}

Values are presented as mean \pm standard deviation or number (\%) $M e t S(+)$ positive metabolic syndrome, MetS(-) negative metabolic syndrome, SBP systolic blood pressure, DBP diastolic blood pressure, MAP mean arterial pressure, $P P$ pulse pressure, IMT intima-media thickness 

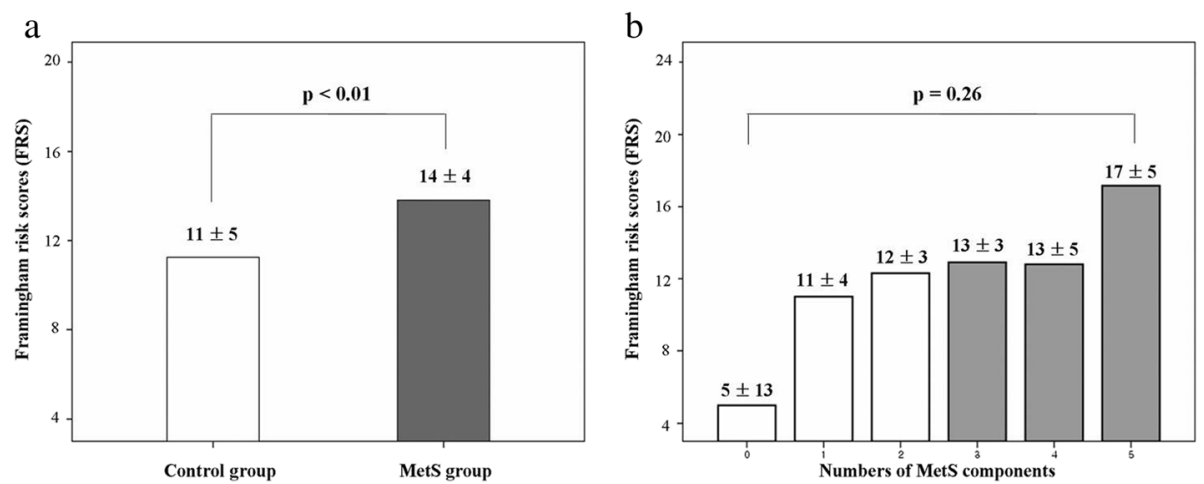

Fig. 1 a Differences in FRS between MetS(+) and MetS(-) group and (b) among five groups classified by the number of MetS components. FRS, Framingham risk score; MetS, metabolic syndrome

was no significant difference in FRS among five groups classified by the number of MetS components $(0,5 \pm 13$; $1,11 \pm 4 ; 2,12 \pm 3 ; 3,13 \pm 3 ; 4,13 \pm 5 ; 5,17 \pm 5 ; p=0.26$ ) (Fig. 1b). The ABI was significantly lower in the MetS group than in the control group ( $1.2 \pm 0.1$ vs. $1.1 \pm 0.2, p=$ 0.03 ) and the PWVaor was significantly higher in the MetS(+) than MetS(-) group $(7.0 \pm 1.4 \mathrm{~m} / \mathrm{s}$ vs. $8.4 \pm 1.6 \mathrm{~m} /$ $\mathrm{s}, p<0.01$ ) (Fig. 2a). There was no significant difference between the control and MetS group in PWVarm (8.0 \pm $1.5 \mathrm{~m} / \mathrm{s}$ vs. $8.8 \pm 1.2 \mathrm{~m} / \mathrm{s}, p=0.07$ ) (Fig. 2b) and PWVleg $(9.4 \pm 1.4 \mathrm{~m} / \mathrm{s}$ vs. $9.6 \pm 1.6 \mathrm{~m} / \mathrm{s}, p=0.68)$ (Fig. $2 \mathrm{c}$ ), respectively. The right and left mean IMT was higher in the MetS(+) than MetS(-) group (right mean IMT: 0.94 \pm $0.20 \mathrm{~mm}$ vs. $0.81 \pm 0.20 \mathrm{~mm}, p=0.03$; left mean IMT: 0.93 $\pm 0.20 \mathrm{~mm}$ vs. $0.79 \pm 0.20 \mathrm{~mm}, p=0.03$, respectively).

PWVaor positively correlated with FRS $(r=0.31, p=0.03)$ and PWVarm $(r=0.67, p<0.01)$, respectively (Table 2$)$. Among the non-invasive tools, PWVaor was an independent tool for predicting the probability of the presence of MetS ( $p=0.04$; odds ratio, 1.88 ; $95 \%$ confidence interval, 1.03 to 3.42) (Table 3). A cut-off value of PWVaor of $7.4 \mathrm{~m} / \mathrm{s}$ showed a sensitivity of $66.7 \%$ and a specificity of
$47.6 \%$ for predicting the probability of the presence of MetS (Fig. 3).

\section{Discussion}

MetS is a well known accelerator of central arterial aging and it is associated with an increased risk of cardiovascular events [3-5]. The present study comparing individuals with MetS and controls showed that FRS, PWVaor and both carotid mean IMT were significantly higher.

MetS is a risk factor for the development of coronary artery disease (CAD) and cardiovascular events. Several studies elucidated the relationships between MetS and FRS, which estimates 10-year risk of CHD. Based on data from women with suspected myocardial ischemia, Marroquin et al. [13] suggested that MetS modifies the cardiovascular risk associated with angiographic CAD. Specifically, MetS was found to be a predictor of 4-year cardiovascular risk only when associated with significant angiographic CAD. Iribarren et al. [14] reported that the presence of MetS imparts a high risk of early-onset clinical CAD, but the prognostic information associated with the syndrome is not greater than the sum of its
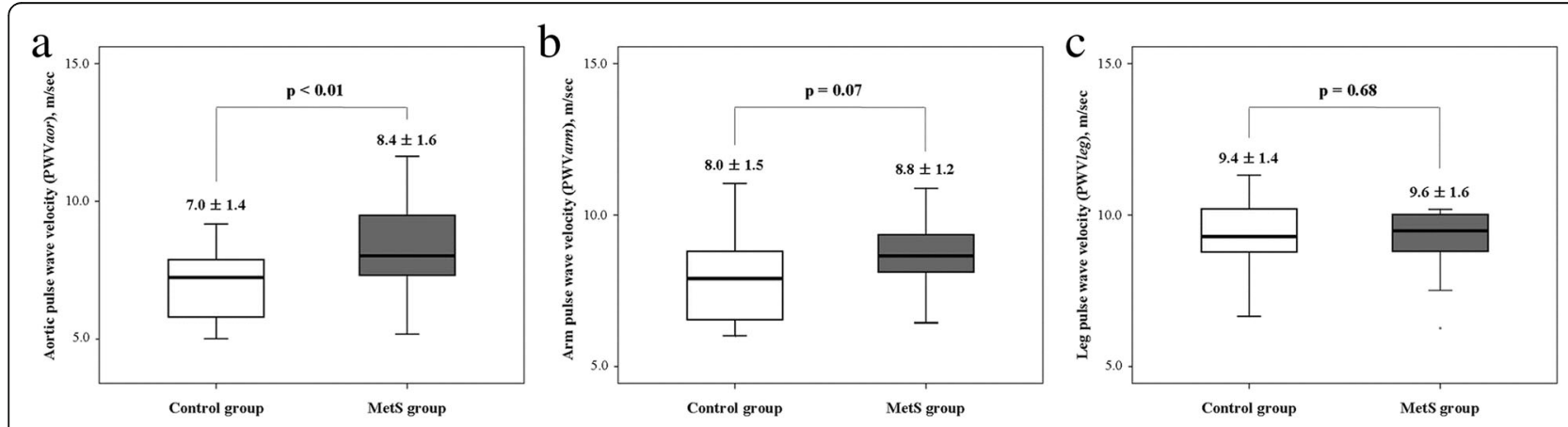

Fig. 2 Difference in PWV of the a aorta, $\mathbf{b}$ arm, and $\mathbf{c}$ leg between the MetS and control group. PW, pulse wave velocity; MetS, metabolic syndrome; PWVaor, pulse wave velocity of the aorta; PWVarm, pulse wave velocity of the arm; PWVleg, pulse wave velocity of the leg 
Table 2 The relationships among the non-invasive methods for the detection of vascular aging

\begin{tabular}{|c|c|c|c|c|c|c|}
\hline \multirow[t]{2}{*}{ Variable } & \multicolumn{2}{|l|}{ FRS } & \multicolumn{2}{|l|}{ PWaor } & \multicolumn{2}{|c|}{ Right mean IMT } \\
\hline & Coefficient & $p$-value & Coefficient & $p$-value & Coefficient & $p$-value \\
\hline FRS & - & - & 0.31 & 0.03 & 0.44 & $<0.01$ \\
\hline Ankle-brachial index & 0.01 & 0.95 & 0.27 & 0.07 & 0.13 & 0.37 \\
\hline PWVaor (m/sec) & 0.31 & 0.03 & - & - & 0.27 & 0.11 \\
\hline PWVarm (m/sec) & 0.08 & 0.61 & 0.67 & $<0.01$ & 0.11 & 0.45 \\
\hline PWVleg (m/sec) & 0.14 & 0.36 & 0.18 & 0.22 & 0.08 & 0.60 \\
\hline Augmentation index (\%) & 0.23 & 0.14 & -0.08 & 0.61 & 0.32 & 0.04 \\
\hline Subendocardial viability ratio (\%) & -0.02 & 0.91 & -0.11 & 0.48 & 0.17 & 0.28 \\
\hline Ejection duration (ms) & -0.15 & 0.34 & 0.13 & 0.43 & -0.08 & 0.64 \\
\hline Right mean IMT (mm) & 0.44 & $<0.01$ & 0.24 & 0.11 & - & - \\
\hline Left mean IMT (mm) & 0.45 & $<0.01$ & 0.26 & 0.09 & 0.71 & $<0.01$ \\
\hline
\end{tabular}

FRS Framingham risk score, PWVaor pulse wave velocity of the aorta, IMT intima-media thickness, PWVarm pulse wave velocity of the arm, PWVleg pulse wave velocity of the leg

parts. In the present study, FRS was significantly higher in the MetS than control group. Furthermore, there was no significant difference in FRS among five groups classified by the number of MetS components, which warrant further investigation.

Although our results did not show a significant difference between the control group and the MetS group in PWVarm and PWVleg, the PWVaor was significantly increased in the MetS group. In some studies with respect to ABI as an indicator of the presence of PAD of the lower extremities, Vogt et al. [6] showed that the $\mathrm{ABI}$ associated with mortality in elderly women, and Zheng et al. [7] reported the association with clinical CHD, stroke and preclinical carotid and popliteal atherosclerosis in middle-aged adults. It is well established that the PWVaor as an indicator of systemic vascular aging, arterial compliance or stiffness, elastic modulus, impedance, and pulse pressure amplification, which significantly and independently associated with both target organ damage and increased risk for cardiovascular morbidity and mortality [15-17]. Recently, Roman et al. [18] reported that central aortic pressure more accurately reflects loading conditions of the left ventricular myocardium, coronary arteries, and cerebral vasculature and thereby, in theory, more strongly relates to vascular disease and outcome than does brachial pressure and suggested the use of central blood pressure as a treatment target in future trials.

Although a PWV $>10 \mathrm{~m} / \mathrm{s}$ has been suggested as a conservative estimate of significant alterations of aortic function according to the 2007 guidelines for the management of arterial hypertension of the European Society of Hypertension and of the European Society of Cardiology [19], our investigation revealed that, among non-invasive tools including FRS and carotid IMT, PWVaor was an independent tool for predicting the probability of the presence of MetS, and that a cut-off value of PWVaor of $7.4 \mathrm{~m} / \mathrm{s}$ shows a sensitivity of $66.7 \%$ and a specificity of $47.6 \%$ for predicting the probability of the presence of MetS. Blacher et al. [20] showed that $\mathrm{PWV}>12.0 \mathrm{~m} / \mathrm{s}$ was associated with higher cardiovascular morbidity and mortality than PWV $<9.4 \mathrm{~m} / \mathrm{s}$ in patients with end-stage renal disease. Therefore, the clinical interpretation and availability of these techniques is largely

Table 3 Multivariate logistic regression analysis

\begin{tabular}{lclc}
\hline Variable & Adjusted odds ratio & $95 \%$ Confidence interval & $p$-value \\
\hline PWV of the aorta & 1.88 & $1.03-3.42$ & 0.04 \\
Ankle-brachial index & 0.02 & $0.00-3.34$ & 0.14 \\
Augmentation index (\%) & 1.03 & $0.98-1.08$ & 0.27 \\
Subendocardial viability ratio (\%) & 0.99 & $0.96-1.03$ & 0.69 \\
Ejection duration (ms) & 1.00 & $0.98-1.02$ & 0.73 \\
Framingham risk score & 1.04 & $0.05-1.25$ & 0.69 \\
Right mean IMT & 8.29 & $0.02-276.36$ & 0.42 \\
Left mean IMT & 2.08 & 0.77 \\
\hline
\end{tabular}

Aortic PWV was an independent tool for predicting the probability of the presence of metabolic syndrome $P W V$ pulse wave velocity, IMT intima-media thickness 


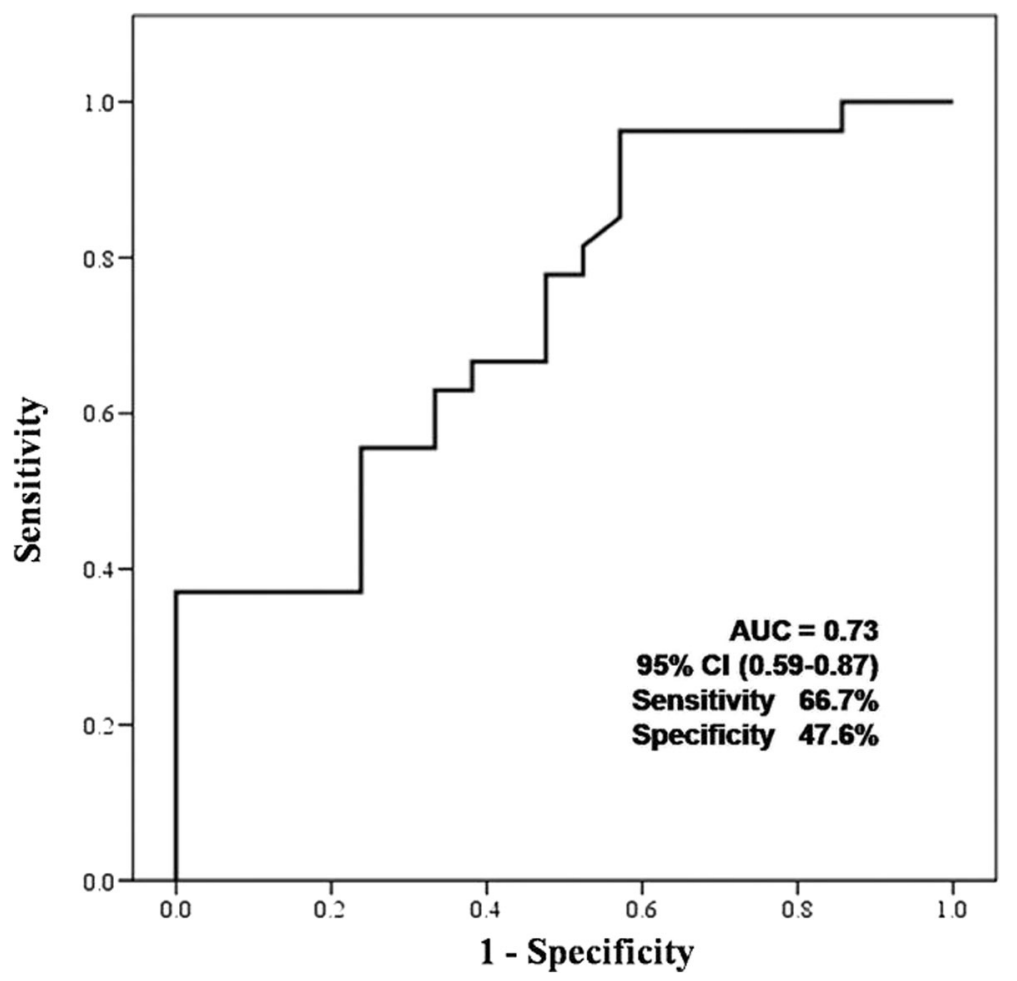

Fig. 3 Receiver operating characteristic curve. A cut-off value of pulse wave velocity of the aorta of $7.4 \mathrm{~m} / \mathrm{s}$ shows a sensitivity of $66.7 \%$ and a specificity of $47.6 \%$ for predicting the probability of the presence of metabolic syndrome. AUU, area under curve; Cl, confidence interval

limited and additional research is needed to elucidate and explain the value of PWV.

Our results revealed that both carotid mean IMT was higher in the MetS than control group. In several studies on whether MetS predicts the progression of carotid atherosclerosis, Iglseder et al. [21] reported MetS as a stronger risk factor for early carotid atherosclerosis in women, and Ahluwalia et al. [22] documented that MetS is associated with subclinical atherosclerosis using the biomarkers. Therefore, based on the present results, we suggest that MetS can play a role in the progression of subclinical carotid atherosclerosis.

Several limitations are considered in the present study. One, subclinical atherosclerosis as a vascular aging can be divided into two categories: those which increase central arterial stiffness, and those which decrease endothelial responsiveness. Although our results are in concordance with PWVaor increase reflecting arterial stiffness in the MetS group, no data are provided on endothelial responsiveness to detect the initial progression of subclinical atherosclerosis as a vascular aging such as results from acetylcholine stimulation tests, flow-mediated dilation and strain gauge plethysmography for the Mets and controls group, which warrants further investigation via large population together with longer-term follow-up studies are required.
Another, several studies revealed that AIx differs markedly according to the difference in the study population, such as in age, gender, health status and smoking behavior [23-26]. Moreover, the time points (diurnal variations) at which AIx measurements were obtained are not reported in the present study, therefore requiring further investigation, including SEVR, ED, PWVarm, PWVleg as well as Aix [27, 28].

\section{Conclusions}

In conclusion, among the non-invasive tools for the detection of vascular stiffness as a vascular aging in never-treated individuals with MetS, the PWVaor was an independent tool for predicting the probability of the presence of MetS. We suggest that PWVaor, combined with traditional tools, can play an important role as a complementary or alternative tool for the detection of vascular stiffness in never-treated individuals with MetS.

\section{Acknowledgements}

This study was supported by a grant of the Seoul R \& BD Program of the Republic of Korea (\#10526).

Availability of data and materials Not applicable. 


\section{Authors' contributions}

$\mathrm{LD}$ and $\mathrm{YH}$ designed the study, performed the experiments, analyzed the results and wrote the manuscript. $C W, C Y, L J, P C, J H, J H$, and $L M$ contributed data analysis. All authors read and approved the final manuscript.

\section{Competing interests}

The authors declare that they have no competing interests.

\section{Consent for publication}

Not applicable.

\section{Ethics approval and consent to participate}

This study was approved by the Institutional Review Committee of St Mary's Hospital, the Catholic University of Korea and conducted in agreement with the Declaration of Helsinki (SC 14RISI0006).

\section{Received: 15 December 2016 Accepted: 19 December 2016} Published online: 06 January 2017

\section{References}

1. Expert Panel on Detection, Evaluation, and Treatment of High Blood Cholesterol in Adults. Executive summary of the third report of the National Cholesterol Education Program (NCEP) expert panel on detection, evaluation, and treatment of high blood cholesterol in adults (Adult Treatment Panel III). JAMA. 2001;285:2486-97.

2. Grundy SM, Cleeman JI, Daniels SR, Donato KA, Eckel RH, Franklin BA, Gordon DJ, Krauss RM, Savage PJ, Smith Jr SC, Spertus JA, Costa F, American Heart Association; National Heart, Lung, and Blood Institute. Diagnosis and management of the metabolic syndrome: an American Heart Association/ National Heart, Lung, and Blood Institute Scientific statement. Circulation. 2005;112:2735-52.

3. Gami AS, Witt BJ, Howard DE, Erwin PJ, Gami LA, Somers VK, Montori VM. Metabolic syndrome and risk of incident cardiovascular events and death: a systematic review and meta-analysis of longitudinal studies. J Am Coll Cardiol. 2007:49:403-14.

4. Scuteri A, Najjar SS, Muller DC, Andres R, Hougaku H, Metter EJ, Lakatta EG. Metabolic syndrome amplifies the age-associated increases in vascular thickness and stiffness. J Am Coll Cardiol. 2004;43:1388-95.

5. Scuteri A, Najjar SS, Morrell CH, Lakatta EG, Cardiovascular Health Study. The metabolic syndrome in older individuals: prevalence and prediction of cardiovascular events: the Cardiovascular Health Study. Diabetes Care. 2005;28:882-7.

6. Vogt MT, Cauley JA, Newman AB, Kuller LH, Hulley SB. Decreased ankle/arm blood pressure index and mortality in elderly women. JAMA. 1993;270:465-9.

7. Zheng ZJ, Sharrett AR, Chambless LE, Rosamond WD, Nieto FJ, Sheps DS, Dobs A, Evans GW, Heiss G. Associations of ankle-brachial index with clinical coronary heart disease, stroke and preclinical carotid and popliteal atherosclerosis: the Atherosclerosis Risk in Communities (ARIC) Study. Atherosclerosis. 1997:131:115-25.

8. Cruickshank K, Riste L, Anderson SG, Wright JS, Dunn G, Gosling RG. Aortic pulse-wave velocity and its relationship to mortality in diabetes and glucose intolerance: an integrated index of vascular function? Circulation. 2002:106:2085-90.

9. Willum-Hansen T, Staessen JA, Torp-Pedersen C, Rasmussen S, Thijs L, Ibsen H, Jeppesen J. Prognostic value of aortic pulse wave velocity as index of arterial stiffness in the general population. Circulation. 2006;113:664-70.

10. O'Leary DH, Polak JF, Kronmal RA, Manolio TA, Burke GL, Wolfson Jr SK. Carotid-artery intima and media thickness as a risk factor for myocardial infarction and stroke in older adults. Cardiovascular Health Study Collaborative Research Group. N Engl J Med. 1999:340:14-22.

11. Lorenz MW, Markus HS, Bots ML, Rosvall M, Sitzer M. Prediction of clinical cardiovascular events with carotid intima-media thickness: a systematic review and meta-analysis. Circulation. 2007;115:459-67.

12. Hodis HN, Mack WJ, LaBree L, Selzer RH, Liu CR, Liu CH, Azen SP. The role of carotid arterial intima-media thickness in predicting clinical coronary events. Ann Intern Med. 1998;128:262-9.

13. Marroquin OC, Kip KE, Kelley DE, Johnson BD, Shaw LJ, Bairey Merz CN, Sharaf BL, Pepine CJ, Sopko G, Reis SE, Women's Ischemia Syndrome Evaluation Investigators. Metabolic syndrome modifies the cardiovascular risk associated with angiographic coronary artery disease in women: a report from the Women's Ischemia Syndrome Evaluation. Circulation. 2004;109:714-21.
14. Iribarren C, Go AS, Husson G, Sidney S, Fair JM, Quertermous T, Hlatky MA, Fortmann SP. Metabolic syndrome and early-onset coronary artery disease: is the whole greater than its parts? J Am Coll Cardiol. 2006;48:1800-7.

15. Jankowski P, Kawecka-Jaszcz K, Czarnecka D, Brzozowska-Kiszka M, Styczkiewicz K, Loster M, Kloch-Badelek M, Wilinski J, Curyło AM, Dudek D, Aortic Blood Pressure and Survival Study Group. Pulsatile but not steady component of blood pressure predicts cardiovascular events in coronary patients. Hypertension. 2008;51:848-55.

16. Pini R, Cavallini MC, Palmieri V, Marchionni N, Di Bari M, Devereux RB, Masotti G, Roman MJ. Central but not brachial blood pressure predicts cardiovascular events in an unselected geriatric population: the ICARe Dicomano study. J Am Coll Cardiol. 2008;51:2432-9.

17. Wang KL, Cheng HM, Chuang SY, Spurgeon HA, Ting CT, Lakatta EG, Yin FC, Chou P, Chen CH. Central or peripheral systolic or pulse pressure: which best relates to target organs and future mortality? J Hypertens. 2009;27:461-7.

18. Roman MJ, Devereux RB, Kizer JR, Lee ET, Galloway JM, Ali T, Umans JG, Howard BV. Central pressure more strongly relates to vascular disease and outcome than does brachial pressure: the Strong Heart Study. Hypertension. 2007:50:197-203.

19. Mancia G, Fagard R, Narkiewicz K, Redon J, Zanchetti A, Böhm M, Christiaens T, Cifkova R, De Backer G, Dominiczak A, Galderisi M, Grobbee DE, Jaarsma T, Kirchhof P, Kjeldsen SE, Laurent S, Manolis AJ, Nilsson PM, Ruilope LM, Schmieder RE, Sirnes PA, Sleight P, Viigimaa M, Waeber B, Zannad F, Redon J, Dominiczak A, Narkiewicz K, Nilsson PM, Burnier M, Viigimaa M, Ambrosioni E, Caufield M, Coca A, Olsen MH, Schmieder RE, Tsioufis $C$, van de Borne $P$, Zamorano $J$, Achenbach S, Baumgartner $H$, Bax JJ, Bueno H, Dean V, Deaton C, Erol C, Fagard R, Ferrari R, Hasdai D, Hoes AW, Kirchhof P, Knuuti J, Kolh P, Lancellotti P, Linhart A, Nihoyannopoulos P, Piepoli MF, Ponikowski P, Sirnes PA, Tamargo JL, Tendera M, Torbicki A, Wijns W, Windecker S, Clement DL, Coca A, Gillebert TC, Tendera M, Rosei EA, Ambrosioni E, Anker SD, Bauersachs J, Hitij JB, Caulfield M, De Buyzere M, De Geest S, Derumeaux GA, Erdine S, Farsang C, Funck-Brentano C, Gerc V, Germano G, Gielen S, Haller H, Hoes AW, Jordan J, Kahan T, Komajda M, Lovic D, Mahrholdt H, Olsen MH, Ostergren J, Parati G, Perk J, Polonia J, Popescu BA, Reiner Z, Rydén L, Sirenko Y, Stanton A, Struijker-Boudier H, Tsioufis C, van de Borne P, Vlachopoulos C, Volpe M, Wood DA. 2013 ESH/ESC guidelines for the management of arterial hypertension: the Task Force for the Management of Arterial Hypertension of the European Society of Hypertension (ESH) and of the European Society of Cardiology (ESC). Eur Heart J. 2013:34:2159-219.

20. Blacher J, Guerin AP, Pannier B, Marchais SJ, Safar ME, London GM. Impact of aortic stiffness on survival in end-stage renal disease. Circulation. 1999;99:2434-9.

21. Iglseder B, Cip P, Malaimare L, Ladurner G, Paulweber B. The metabolic syndrome is a stronger risk factor for early carotid atherosclerosis in women than in men. Stroke. 2005;36:1212-7.

22. Ahluwalia N, Drouet L, Ruidavets JB, Perret B, Amar J, Boccalon H, HanaireBroutin $\mathrm{H}$, Ferrières J. Metabolic syndrome is associated with markers of subclinical atherosclerosis in a French population-based sample. Atherosclerosis. 2006:186:345-53.

23. Kawasaki T, Sasayama S, Yagi S, Asakawa T, Hirai T. Non-invasive assessment of the age related changes in stiffness of major branches of the human arteries. Cardiovasc Res. 1987;21:678-87.

24. Hayward CS, Kelly RP. Gender-related differences in the central arterial pressure waveform. J Am Coll Cardiol. 1997;30:1863-71.

25. Weber T, Auer J, O'Rourke MF, Kvas E, Lassnig E, Berent R, Eber B. Arterial stiffness, wave reflections, and the risk of coronary artery disease. Circulation. 2004;109:184-9.

26. Mahmud A, Feely J. Effect of smoking on arterial stiffness and pulse pressure amplification. Hypertension. 2003;41:183-7.

27. Kim YS, Kim SY, Bae JH, Nah DY, Rhee MY, Lee MM, Huh HJ, Chae SL, Kim YK. Telmisartan versus carvedilol in hypertensive patients with metabolic syndrome: effects on blood pressure, arterial stiffness, blood glucose, and lipid metabolism. J Korean Soc Hypertens. 2010;16:44-53.

28. Seo SM, Jung HO, Koh YS, Park CS, Park HJ, Oh YS, Back SH, Youn HJ, Chung WS, Seung KB, Kim JH. Comparison of the effect of angiotensin II receptor blocker and calcium channel blocker on arterial stiffness in middle aged subjects with essential hypertension: using the changes in central aortic pressure, carotid stiffness, pulse wave velocity, and biomarkers. J Korean Soc Hypertens. 2009;15:20-31. 